\title{
To, co publiczne i prywatne w szkolnictwie wyższym. Synteza podejścia ekonomicznego i politycznego
}

STRESZCZENIE. Rozróżnienie na to, co publiczne i to, co prywatne, ma kluczowe znaczenie dla szkolnictwa wyższego. Jednak nie ma powszechnej zgody co do samej istoty „tego, co publiczne”. Na gruncie neoklasycznej teorii ekonomicznej Paul Samuelson odróżnia dobra nierynkowe (publiczne), które nie mogą być wytwarzane dla zysku, od działań rynkowych (prywatnych). To rozróżnienie stanowi podstawę ustalania minimalnego niezbędnego poziomu publicznych wydatków. Nie jest jednak w stanie objąc dóbr kolektywnych oraz składników normatywnych. W teorii politycznej „to, co publiczne" często rozumiane jest jako własność i/lub kontrola państwowa. John Dewey uznaje dane operacje społeczne za „publiczne”, gdy niosą konsekwencje pokrewne dla osób innych niż bezpośrednio zaangażowane w dane działania. W ten sposób stają się one przedmiotem troski państwowej. Jest to rozróżnienie znacznie bardziej pojemne niż to proponowane przez Samuelsona, jednakże nie pozwala na nakładanie ograniczenia na koszty. Żadna z tych definicji nie jest satysfakcjonująca, ale każda ma nam coś do zaoferowania oraz może zostać wykorzystana do krytycznego zbadania tej drugiej. W niniejszym artykule dokonano syntezy tych dwóch podejść, wykorzystując powstałą w jej wyniku ramę zawierającą cztery kwadranty (społeczeństwo obywatelskie, socjaldemokrację, państwowy quasi-rynek oraz rynek komercyjny) do analizy szkolnictwa wyższego i badań.

SŁOWA KLUCZOWE: rola szkolnictwa wyższego, równość, neoliberalizm, polityka publiczna, rynek edukacyjny

\section{Wstęp}

Istnieje niemal powszechna zgoda, że szkolnictwo wyższe ma istotny wkład w całokształt stosunków społecznych, jak również w publiczny wymiar społeczeństwa. Nie ma jednak jasności, co to właściwie oznacza i w jaki sposób wiąże się z prywatnymi korzyściami czerpanymi przez studentów i absolwentów. Ministrowie szkolnictwa wyższego oraz władze uniwersytetów twierdzą, że instytucje szkolnictwa wyższego 
(ISW) przyczyniają się do „wspólnego dobra”, „interesu publicznego”, „dobra publicznego” czy mają wkład w pulę „dóbr publicznych”. Mówi się, że ISW zapewniają szansę wszystkim według ich osiągnięć; poszerzają zakres możliwości społecznego awansu; wzmacniają kariery i poprawiają życie tych, których kształcą; przyczyniają się do wzrostu wydajności i dobrobytu poprzez przygotowywanie absolwentów do konkretnych zawodów oraz zapewnianie innowacji, z których może korzystać przemysł; dają zatrudnienie w miastach i regionach; tworzą i rozpowszechniają wiedzę i idee, jak również sprzyjają wolności wypowiedzi; pielęgnują biegłość naukową, podtrzymują intelektualną debatę oraz stymulują działania artystyczne; mają też wkład w ustawodawstwo i rządy oraz przygotowują obywateli do demokratycznego podejmowania decyzji. Uważa się, że ISW sprzyjają rozwojowi kosmopolitycznego światopoglądu i stymulują międzynarodową komunikację. Wspierają ekologiczną świadomość oraz znajdują rozwiązania globalnych problemów. Jednakże stwierdzenia dotyczące publicznych korzyści wynikających z działalności szkolnictwa wyższego często pozbawione są intelektualnej precyzji. Odczytuje się je najczęściej jako normatywne i wynikające ze z góry przyjętych założeń. W odróżnieniu od wskaźników prywatnych zwrotów z wykształcenia i przyszłego zatrudnienia, publiczne korzyści rzadko powiązane są z przekonującymi miernikami (Marginson 2015). Również publiczny wymiar nie jest rozumiany jako jednolite pole, w ramach którego funkcjonowałaby jedna definicja „tego, co publiczne”, przechodząca przez cały zakres rozpoznanych działań i efektów.

\section{Przeszkody na drodze do rozjaśnienia „publicznego" szkolnictwa wyższego}

Istnieją przynajmniej cztery powody braku jasności w kwestii rozróżnienia na to, co publiczne i prywatne w szkolnictwie wyższym i innych obszarach. Po pierwsze, terminologia dotycząca tego, co publiczne i prywatne jest w różny sposób stosowana do umiejscawiania danej aktywności (sektor państwowy vs. zewnętrze), źródeł finansowania (rządowe vs. budżety domowe lub organizacje prywatne) oraz istoty danej aktywności. Choć w niniejszym artykule zostanie dokonane rozróżnienie na to, co publiczne i prywatne w kategoriach społecznej istoty aktywności edukacyjnej, rozumienie tego, co „publiczne” jako sektora państwowego czy rządowego ujęte jest w tym podejściu. Finansowanie postrzegane jest tu jako coś drugorzędnego względem samej istoty oraz umiejscowienia danej aktywności.

Po drugie, rozróżnienie na to, co publiczne i prywatne różni się na całym świecie w zależności od dominującej kultury politycznej. Weźmy pod uwagę różne sposoby rozumienia i praktyki tego, co „publiczne”, „prywatne”, „społeczeństwa” i „panstwa" w realiach nordyckich, niemieckim uspołecznionym rynku, społeczeństwach anglosaskich z ich ograniczonymi liberalnymi państwami oraz chińskiej tradycji 
cywilizacyjnej z jej silną rodziną oraz kompleksową praktyką porządku państwowego. Relacja nakładów publicznych i prywatnych jest różna w często podobnych pod innymi względami systemach krajowych (OECD 2014: 260-276), odzwierciedlając różne założenia dotyczące zakresu obowiązków rządów, rodzin i samych studentów. Różnice między krajowym prawem w tym zakresie nie zostały w niniejszym artykule przebadane, niemniej przedstawia się tu pewną ramę analityczną, którą można przetestować w odmiennych kontekstach. Powrócimy do tej kwestii w części poświęconej wnioskom.

Po trzecie, to, co publiczne i prywatne rozumiane jest w różny sposób w różnych naukach społecznych, od ekonomii po wszelkie nurty teorii politycznej i komunikacyjnej (Marginson 2007; 2011; 2015).

Po czwarte, w ostatnim półwieczu w anglosaskich naukach społecznych obserwowaliśmy silny i długotrwały atak na pojęcia dobra publicznego oraz interesu publicznego, wskutek czego częściowo zaciemniono publiczny wymiar szkolnictwa wyższego i innych sektorów. Źródła tej krytyki dobra publicznego leżą w zimnowojennej argumentacji rozwiniętej przez Kennetha Arrowa (1951/2012) oraz teoretyków wyboru publicznego (Buchanan i Tullock 1962), mówiącej, że posiadanie wspólnego interesu publicznego, przekraczającego indywidualne preferencje, jest niemożliwe. James M. Buchanan skierował swoją pracę przeciwko temu, co określił mianem „normatywnego złudzenia, wywodzącego się z Heglowskiego idealizmu: państwo było, w jakiś sposób, dobroczynnym bytem, a ci, którzy podejmowali decyzje w jego imieniu, postrzegani byli przez pryzmat konieczności uwzględnienia ogólnego bądź "publicznego interesu «" (Buchanan i Tullock 1962: 133). Sam jednak uważał, że jednostki wykorzystują politykę w celu poszukiwania form sprawiedliwości i organizacji społecznej, które sprzyjają ich jednostkowym interesom. Polityczni przywódcy mogą twierdzić, że są odpowiedzialni przed osobami czy sprawami innymi niż oni sami, ale w gruncie rzeczy nie są. W jego ujęciu polityka była bowiem kolejnym rynkiem, zaś decyzje grupowe stanowiły sumę indywidualnych wyborów powiązanych ze sobą przez same zasady podejmowania decyzji (Buchanan i Tullock 1962: 12, 35, 95, 132, 284, 305-306, 314-315). Chociaż stanowisko to nie jest powszechnie podzielane w naukach społecznych, to odcisnęło swoje piętno na neoliberalnym ograniczaniu państwowych polityk (Marginson 2016b). Dzięki temu właśnie anglosaska polityka w zakresie szkolnictwa wyższego skupia się dziś na prywatnych korzyściach studentów/absolwentów, przede wszystkim wyższych zarobkach, oraz ich indywidualnych wyborach i satysfakcji konsumenckiej. Nacisk położony na prywatne korzyści, zgodny z marketingowym etosem, który opanował wiele ISW, wykorzystany jest do uzasadnienia istnienia opłat za studia. Publiczny wymiar zdefiniowany jest wąsko, w kategoriach gospodarki rynkowej, w której indywidualne korzyści są najważniejsze. Wobec tego za najistotniejszą funkcję publiczną ISW uważa się ich wkład w zyskowność, innowacje przemysłowe oraz wzrost gospodarczy - nawet jeśli to rząd, bardziej niż przemysł, kształtuje poję- 
cie gospodarczej użyteczności w szkolnictwie wyższym (Geiger i Sa 2009: 209). Neoliberalne rządy mogą nie chcieć definiować, monitorować, mierzyć (tam, gdzie to możliwe) czy regulować wspólnie wykorzystywanych kolektywnych wyników kształcenia w rodzaju umiejętności społecznych. Takie rezultaty są dziś w niewystarczającym stopniu rozpoznane, niedofinansowane, niedostatecznie wytwarzane, co utrwala ich marginalną pozycję.

W obszarze głównego nurtu polityki publicznej powszechna jest realizacja zaledwie jednego kolektywnego celu społecznego (choć jego zastosowanie jest zróżnicowane) - wkład ISW w społeczną sprawiedliwość. Innego rodzaju wkłady są często postrzegane jako efekty uboczne zapewniania korzyści absolwentom, bardziej niż cele polityczne. Wynikają one być może częściowo z przypadku, wskutek wsparcia szkolnictwa wyższego, ale uważa się, że stanowią wyłącznie jego własny obszar odpowiedzialności. W ten sposób można ograniczyć obciążenia fiskalne spoczywające na rządzie, ale zawęża to zakres publicznego sprawstwa, a także zwiększa ryzyko niedostatecznego zapewniania dóbr publicznych. W ramach publicznej roli szkolnictwa wyższego, zdecentralizowanej i przeniesionej z poziomu systemowego na poziom instytucji, niektóre ISW utrzymują zaskakująco silne misje publiczne. W Kalifornii, w latach 2012-2013, na Uniwersytecie Kalifornijskim, w tym na kampusach Berkeley i Los Angeles, przyjęto ponad 20 tys. studentów z Pell grants ${ }^{1}$, pochodzących z rodzin z dochodami poniżej 50 tys. dolarów rocznie - to znaczy więcej niż w najlepszych szesnastu prywatnych uniwersytetach w Stanach Zjednoczonych razem wziętych (Dirks 2015). W więcej niż $1 / 4$ tych rodzin żaden z rodziców nie posiadał wyższego wykształcenia (Rothblatt 2012: 272). Jednak nie wszystkie uniwersytety mogą tak postępować. Nie są w stanie zastępować państw. Muszą uwzględniać własną trwałość, a inaczej niż państwa nie mogą zmianić całego systemu, by zwiększyć wspólne korzyści. Są mniej transparentne i nie są w pełni włączone do sfery publicznej poprzez mechanizm demokratyczny.

\section{Porządek wywodu}

W jaki sposób nauki społeczne mogą skuteczniej działać na rzecz przywracania znaczenia wymiarowi publicznemu? Niniejszy artykuł koncentruje się na dwóch szeroko wykorzystywanych dyscyplinarnych podejściach do rozróżniania na to, co publiczne i prywatne, zaczerpniętych odpowiednio z teorii ekonomicznej i teorii politycznej. Ekonomiczna definicja, reprezentowana tu przez koncepcje Samuelsona (1954), odróżnia czynności nierynkowe od rynkowych. Definicja polityczna, którą z kolei reprezentuje John Dewey (1927), rozróżnia czynności posiadane i/lub

${ }^{1}$ Pell grants - forma pomocy publicznej adresowana do studentów pochodzących z rodzin o niskich dochodach, którzy nie ukończyli jeszcze studiów na poziomie licencjackim, organizowana przez federalny rząd Stanów Zjednoczonych - przyp. tłum. 
kontrolowane przez państwa oraz aktywności, które nie są przez nie posiadane ani kontrolowane.

Po zarysowaniu obu podejść do rozróżniania na to, co publiczne i prywatne niniejszy artykuł łączy je w analityczną ramę, która może posłużyć do dalszych badań i analizy ustawodawstwa w zakresie szkolnictwa wyższego. Przy tym zwięźle omawia przykłady i zastosowania, w tym odnosi się do zagadnienia globalnych dóbr publicznych.

\section{Samuelsona rozróżnienie na dobra rynkowe i nierynkowe w ekonomii}

W artykule The pure theory of public expenditure Samuelson (1954) sformułował pojęcie tego, co publiczne i prywatne, które dominuje dziś w polityce gospodarczej. Dobra publiczne zostały zdefiniowane jako nierywalizacyjne i uniemożliwiające wykluczenie użytkowników (non-exludable). Dobra są nierywalizacyjne, gdy konsumpcja przez jakąkolwiek liczbę ludzi nie doprowadzi do ich wyczerpania, jest to np. wiedza dotycząca twierdzenia matematycznego, które utrzymuje swoją wartość użytkową w nieskończoność, będąc jednocześnie nieodpłatnie dostępne. Nie da się wykluczyć z użytkowania dobra, gdy korzyści płynące z niego nie mogą zostać ograniczone do indywidualnego nabywcy - jest tak, dajmy na to, w przypadku regulacji dotyczących czystego powietrza. Dobra prywatne nie są ani nierywalizacyjne, ani niemożliwe do wykluczenia. Można je wytwarzać, pakować i sprzedawać jako zindywidualizowane towary na rynkach. Dóbr publicznych oraz częściowo publicznych nie sposób wytworzyć w zyskowny sposób. Wymagają finansowania rządowego bądź wsparcia pozarządowego. Niekoniecznie potrzebują w pełni rządowego finansowania i można je wytwarzać zarówno w państwowych, jak i prywatnych instytucjach.

Samuelsona pojęcie dóbr publicznych i prywatnych ma różne odmiany, w tym dobra wspólnej puli (common-pool goods), rywalizacyjne, ale niepodlegające wykluczeniu, jak choćby obszary łowne; „dobra klubowe” Buchanana (1965), podlegające wykluczeniu, ale nierywalizacyjne do momentu wystąpienia przeludnienia; dobra opłacane (toll goods) Elinor Ostrom (2010), za pomocą których wszyscy poza konkretną populacją są wykluczeni, natomiast w obrębie danej grupy dobro jest nierywalizacyjne. Dobra społecznie pożądane (merit goods), które stanowią dobra wytwarzane zarówno w prywatnych, jak i publicznych sektorach, są rywalizacyjne i umożliwiają wykluczenie użytkowników, są jednak subsydiowane przez rząd w momencie użycia, ponieważ zakłada się, że w innym wypadku będą one podlegać niedostatecznej konsumpcji. Jest tak, ponieważ prywatne korzyści są niejasne i można je czerpać dopiero w długiej perspektywie. Wszystkie te pojęcia mają zastosowanie w szkolnictwie wyższym, ale dalsza dyskusja będzie koncentrować się na podstawowym rozróżnieniu na dobra publiczne i prywatne. 
Choć sformułowana w ogólnych kategoriach definicja Samuelsona nie jest uniwersalna czy stosująca się do wszystkich społeczeństw, obejmuje normy społeczeństwa kapitalistycznego zgodnie z ideą „instytucjonalnego świata”, podzielonego między „własność prywatną wymienianą w otoczeniu rynkowym oraz własność rządową zorganizowaną w ramach hierarchii publicznych" (Ostrom 2010: 642). Nie można jej też zastosować do ekonomii daru (Mauss 2001) czy ekonomii zakorzenionej we wspólnotowej czy administrowanej przez państwo własności i produkcji. Spośród społeczeństw kapitalistycznych najbardziej pasuje do krajów anglosaskich, które pielęgnują pojęcie ograniczonych państw liberalnych Johna Locke’a i Adama Smitha oraz opozycję o sumie zerowej między tym, co prywatne, a tym, co publiczne. W tych krajach państwowe urzędy zajmujące się gospodarką, podobnie jak Samuelson, postrzegają prywatne przedsiębiorstwo jako domyślnego wytwórcę, za wyjątkiem przypadków zawodności rynku na polu produkcji kluczowych dóbr. Tego rodzaju podejście polityczne zwiększa do maksimum zakres handlu oraz akumulacji kapitału, zapewniając jednocześnie podstawę opartą na logice gry o sumie zerowej dla rozdziału na publiczne i prywatne w finansowaniu takich dóbr, jak szkolnictwo wyższe i badania. Rząd finansuje dane dobro, chroniąc przed zawodnością rynku - od tego punktu rynek przejmuje zadanie. Wykorzystując ramę Samuelsona, Walter W. McMahon (2009) w swoim wszechstronnym przeglądzie literatury badawczej wycenia publiczne wkłady uniwersytetów na poziomie około $50 \%$ calkowitych wydatków.

Samuelsona definicja tego, co publiczne i prywatne trafnie rozpoznaje zawodność rynku jako podstawę ustalania niezbędnego poziomu minimum wydatków publicznych na edukację i badania. Jednak jego definicja jest pewnym uproszczeniem, zawierającym luki w rozumowaniu. Po pierwsze, jest to definicja ahistoryczna. Naturalizuje określenie tego, co publiczne i prywatne. To, czy dane dobro jest publiczne, czy prywatne, postrzegane jest jako coś nieodłącznego od istoty danego dobra, powszechnego, niezmiennego i niepowiązanego z kontekstem. Sprawdza się to niekiedy, ale nie zawsze. Jest to prawda w odniesieniu do promieni słonecznych, które zawsze są dobrem publicznym, natomiast błędne, gdy dane dobro jest ukształtowane przez politykę oraz społeczne umowy, a w związku z tym - jak w przypadku szkolnictwa wyższego - może być zarówno publiczne, jak i prywatne.

Drugim problemem jest założenie, że mamy tu do czynienia z grą o sumie zerowej. To znaczy, że jeśli dobro nie jest publiczne, to musi być prywatne i na odwrót. W pewnych okolicznościach, dobra publiczne i dobra prywatne nie stanowią dla siebie alternatywy, ale wzajemnie się uzupełniają. Dajmy na to badania podstawowe na uniwersytetach, wraz z ich powiązaniami z organizacjami komercyjnymi i tymi nienastawionymi na zysk, bezpośrednio i pośrednio generują zarówno publiczne, jak i prywatne dobra w ramach złożonych systemów sprzężeń zwrotnych (Hughes i Kitson 2012). Podobnie rzecz się ma z absolwentami medycyny, zwiększającymi zarówno własne zarobki, jak również publiczny dobrostan, a oba te rodzaje korzyści 
działają na siebie zwrotnie. Polityki publiczne różnią się od siebie w zależności od tego, czy, jak w Wielkiej Brytanii, finansują ISW na podstawie rozdziału o sumie zerowej na publiczne i prywatne koszty oraz korzyści, co podpowiada rozróżnienie Samuelsona, czy też opłacają ISW z podatków, traktując je jako powszechne usługi, w ramach których uznaje się, że prywatne korzyści zawierają się w korzyści publicznej, jak ma to miejsce w przypadku systemów nordyckich. To, czy gra ma sumę zerową, czy dodatnią, jest kwestią wyboru politycznego.

Trzeci problem polega na tym, że definicja Samuelsona nie jest wyposażona w odpowiednie narzędzia, by poradzić sobie z większymi dobrami kolektywnymi, które najczęściej wypadają poza ekonomię, będąc trudne do określenia, obserwowania, mierzenia i wartościowania w kategoriach cen dualnych (shadow prices). Wiele spośród dóbr kolektywnych zawiera silny komponent normatywny - dajmy na to uniwersytety przyczyniają się do wolności akademickiej, ponieważ tworzący je ludzie są przekonani, że stanowi ona cechę istotową samych uniwersytetów. Naturalistyczne sformułowanie Samuelsona nie jest w stanie jednoznacznie poradzić sobie z aspektami normatywnymi. Kwestie normatywne jednak nie znikają. Ekonomiczna identyfikacja dóbr publicznych Samuelsona różni się w zależności od przyjętych przez ekonomistów założeń normatywnych. Neoliberalni ekonomiści mają skłonność do lekceważenia zawodności rynku oraz możliwości zaistnienia dóbr kolektywnych lub zakładają, że publiczne korzyści będą powstawały w charakterze efektu ubocznego prywatnych inwestycji. Socjaldemokraci oraz teoretycy endogenicznego wzrostu mówią o szansach związanych z dobrami publicznymi oraz państwowymi inwestycjami (np. Romer 1990). W sytuacji, w której różnice normatywne są raczej ukryte niż jawne, wnioski prezentowane są jako wynik neutralnego poszukiwania naukowego. Nie pomaga to w rozwiązywaniu realnych problemów. Lepiej jest jednak ujawniać wybory polityczne.

Trzy powyższe problemy są ze sobą wzajemnie powiązane. Na przekór Samuelsonowi, dobra wytworzone rynkowo oraz dobra nierynkowe nie są dwiema stronami tej samej monety. Nie współdzielą jednej ontologii. Rynkowe dobra prywatne muszą być opłacalne w ramach dzisiejszych transakcji rynkowych. Nierynkowe dobra publiczne muszą być politycznie opłacalne, na ich wytwarzanie bowiem, oprócz zawodności rynku, wpływa również wiele innych czynników. Często też funkcjonują w ramach odmiennej czasowości niż dobra rynkowe. Choć definicja Samuelsona jest zbyt minimalistyczna - szczególnie w związku z wykluczaniem relacji o sumie dodatniej między tym, co publiczne, a tym, co prywatne - jej wąska ekonomiczna koncentracja na rzadkości oraz kosztach może być jednak pomocna. Ponadto ustanawiając minimalny poziom niezbędnych świadczeń publicznych, dostarcza refleksyjnej formuły do badania kosztów jakichkolwiek publicznych świadczeń wykraczających poza ten poziom. Samuelson sugeruje, że można mieć bardziej „publiczne” podejście niż minimalnie niezbędne, ale trzeba się liczyć z utraconymi korzyściami. Te same rzadkie zasoby mogłyby być ulokowane gdzie indziej. 


\section{Ekonomiczne dobra publiczne i prywatne w szkolnictwie wyższym}

Zastanówmy się zatem, jakiego rodzaju publiczne i prywatne dobra wytwarzane są w ISW w kategoriach Samuelsona? Najważniejszym nierynkowym dobrem jest wiedza. Od czasów Adama Smitha większość ekonomistów traktowała wiedzę jako formę lub funkcję kapitału (Prendergast 2010), jednak Joseph Stiglitz (1999) wykazał, że wiedza, jak choćby twierdzenie matematyczne jest klasycznym dobrem publicznym w rozumieniu Samuelsona. Nowa wiedza służy wyłącznemu użytkowi swojego twórcy i daje mu przewage „pierwszego poruszyciela”. Patenty zaś zwiększają tę przewagę. Jednakże by wykorzystać wiedzę, należy ją zakomunikować. Gdy już się ją zakomunikuje, istotna wiedza zachowuje swoją wartość niezależnie od tego, jak często jest wykorzystywana. Jest nierywalizacyjna i niepodlegająca wykluczeniu. W związku z tym badania podstawowe są podatne na porażkę rynkową i wszędzie są finansowane przez rządy i organizacje filantropijne. Prawdą jest, że możliwość wykluczenia z użytkowania konkretnych postaci wiedzy, jak teksty czy inne wytwory, może być sztucznie podtrzymywana poprzez mechanizmy własnościowe w rodzaju opłat ochronnych funkcjonujących w czasopismach. Jednakże prywatyzacja nigdy w pełni nie wchodzi w grę, ze względu na łatwość nielegalnej reprodukcji.

Edukacja jest w tym kontekście bardziej niejednoznaczna. Miejsca na studiach w szkolnictwie wyższym mogą stanowić zarówno prywatne, jak i publiczne dobra w ujęciu Samuelsona. Zazwyczaj są (niestałą) mieszaniną obu z nich. Publiczne dobra obejmują zindywidualizowane korzyści nierynkowe, w rodzaju lepszego stanu zdrowia i finansowej biegłości absolwentów (McMahon 2009), oraz zdobytą wiedzę, która nie poddaje się wykluczeniu oraz jest nierywalizacyjna. Jednak za każdym razem, gdy miejsca na studiach wiążą się z uzyskaną za ich pomocą wartością (w odróżnieniu od nieuczestniczenia w systemie), pojawia się rywalizacja; a w ISW, w których mamy nadwyżkę aplikacji przekraczającą liczbę dostępnych miejsc, uczestnictwo podlega wykluczeniu. Rynek w obszarze czesnego staje się wówczas możliwy. Wartość tego rodzaju dóbr prywatnych jest maksymalizowana w programach oferujących studentom możliwości pozycyjne związane z wstępem na określone, rzadkie ścieżki kariery o wysokiej wartości, w rodzaju elitarnego przygotowania w zakresie prawa i medycyny. Są to dobra pozycyjne o sumie zerowej (Hirsh 1976). Gdy jedna osoba zajmuje miejsce na prawie, na Harvardzie, inni nie mają do niego dostępu. Również Liga Bluszczowa tworzy dobra publiczne. Przykładowo, MIT, Harvard czy Stanford oferują wolny dostęp do treści prowadzonych przez nie kursów, nie podważając przy tym prywatnej zawodowej wartości swoich dyplomów zdobywanych w relacjach bezpośrednich oraz powiązanego z tym statusu, jak i możliwości usieciowienia. 
Wiele zależy od tego, w jaki sposób zorganizowane jest szkolnictwo wyższe. $\mathrm{W}$ systemach poddanych daleko idącej stratyfikacji, ustanawiających bariery w postaci czesnego, jak w USA, element dobra prywatnego jest silny. W bardziej powszechnej i mniej konkurencyjnej edukacji w stylu nordyckim większość absolwentów ma podobną pozycję, a miejsca są mniej rywalizacyjne i poddające się wykluczeniu (Välimaa 2011). Niemniej wszyscy nordyccy absolwenci wciąż cieszą się przewagami pozycyjnymi w stosunku do tych, którzy nie uczestniczą w systemie, zaś w niektórych obszarach kształcenia mamy do czynienia z rzadkimi dobrami prywatnymi o wyższej wartości. Fakt, że ich produkcja nie jest sformalizowana na rynku, obniża, ale nie znosi całkowicie zróżnicowania wartości.

\section{Polityczne definicje tego, co publiczne i prywatne}

Niektóre dobra społeczne, w rodzaju obronności narodowej, są z istoty kolektywne. Nie sposób wytwarzać i wykorzystywać ich indywidualnie. Inne dobra, w rodzaju zdrowia publicznego czy edukacji podstawowej, mają kolektywny charakter, ponieważ społeczeństwa chcą, by tak było. Tak czy owak dobra kolektywne często stają się wynikiem procesów podejmowania decyzji i rządowej regulacji. Potencjalnie zakres politycznej regulacji wykracza poza tak zakreślone ramy. Naturalistyczne rozróżnienie Samuelsona w niewystarczającym stopniu uznaje role norm politycznych, procesów politycznych i wyborów w zakresie polityki dotyczących decydowania o tym, co jest prywatne, co publiczne i jak wygląda równowaga między nimi. Wykracza to poza obszar dóbr nierynkowych, obejmując wszystkie dobra poddane politycznej, bardziej niż ekonomicznej, logice. Obejmuje regulację i nadmierne określanie rynków.

Na gruncie teorii politycznej i szerszego pola dyskursu politycznego znajdziemy wiele pojęć tego, co „publiczne”. Jeden z nurtów prezentuje „dobro publiczne” jako wszechstronne i uniwersalne, choć tego rodzaju ujęcie trudno zastosować do kategorii empirycznych. Innym pojęciem są „dobra wspólne” - zasób, który jest współdzielony przez wszystkich, ale nie podlega ograniczeniom związanym z rzadkością występowania (Mansbridge 1998), choć w ramach korzystania z większości otwartych społecznych zasobów często natrafiamy na zatory. Trzecie pojęcie, „sfera publiczna" przyległa do państwa, zostanie omówione poniżej. Prawdopodobnie jednak główna idea tego, co publiczne, w teorii politycznej bazuje na rozróżnieniu na to, co państwowe i niepaństwowe. Chociaż można je odczytywać na wiele sposobów, Dewey przedstawił definicję tego, co publiczne i prywatne jako tego, co państwowe i niepaństwowe. 


\section{Deweya rozróżnienie na to, co państwowe i niepaństwowe}

W książce The Public and its Problems (1927) Dewey zauważa, że choć większość społecznych transakcji dokonuje się w sferze prywatnej, niektóre kwestie dotyczące stosunków społecznych rozumiane są jako kwestie „publiczne”, sprawy szeroko rozumianego „interesu publicznego”, a w związku z tym podejmowane są przez wspólnotę osób („opinię publiczną”). Społeczna transakcja może stać się „publiczna”, gdy posiada pośrednie konsekwencje dla innych, to znaczy osób spoza grupy bezpośrednio zaangażowanej w daną transakcję. „Tym, co publiczne” są wszystkie osoby pośrednio i potencjalnie znajdujące się w sferze oddziaływania (Dewey 1927: 39), niezależnie od tego, czy konsekwencje transakcji są pozytywne, czy negatywne. Dajmy na to, jeśli w jednym mieście wybuchnie epidemia, ludzie w całym kraju są potencjalnie narażeni na płynące z niej zagrożenie. Staje się ona kwestią dotyczącą zdrowia publicznego i wspólnego działania:

Granica między tym, co publiczne a tym, co prywatne, jest [...] wyznaczana na podstawie rozmiaru i zasięgu konsekwencji działań, które są na tyle istotne, by trzeba było je kontrolować, czy to poprzez hamowanie, czy sprzyjanie ich rozwojowi [...]. To, co publiczne, składa się ze wszystkich tych, którzy dotknięci są pośrednimi konsekwencjami transakcji do tego stopnia, że konieczne wydaje się systematyczne zajęcie się tymi konsekwencjami (Dewey 1927: 15-16).

Deweyowska demokratyczna idea „tego, co publiczne”, która była skierowana przeciwko faszyzmowi i stalinizmowi, wyłoniła się z amerykańskiej uczestniczącej tradycji obywatelskiej. Zalecanym przez niego antidotum na zniewalającą władzę był „społeczny proces otwartej kolektywnej deliberacji” oraz racjonalne podejmowanie decyzji na gruncie współdzielonej kultury (Amadae 2003: 130), w których opinia publiczna łączyła się w ramach wpółpartycypacyjnych mediów, partii oraz spotkań publicznych. Za pomocą określonych środków i organów „troszczono się” wówczas o konsekwencje dla stosunków społecznych kwestii uznanych za „publiczne”. Jak twierdzi Dewey, to jest właśnie podstawa działalności państwa. Dana kwestia staje się jednak w pełni publiczną, poddaną rządowej polityce oraz regulacji jedynie, gdy podjęte zostają dwie następujące po sobie decyzje: (a) by traktować ją jako publiczną kwestię z obszaru stosunków społecznych; (b) by podjąć ją za pośrednictwem rządu. Nie wszystkie kwestie dotyczące stosunków społecznych mające konsekwencje zostają uregulowane (np. rozrost Internetu). Z niektórymi kwestiami dotyczącymi stosunków społecznych, dającymi się uznać za sprawy publiczne, radzą sobie organizacje inne niż państwowe agendy (np. organizacje religijne, firmy medialne czy prywatne uniwersytety). Dewey również zauważa, że to, co „publiczne”, nie jest oczywistym dobrem. Nie wszystkie kwestie zatwierdzane 
przez opinię publiczną oraz podejmowane przez rząd przyczyniają się do wzrostu tego, co społeczne, sprawiedliwości czy wspólnych korzyści. Większość nie zawsze ma rację. Dajmy na to państwa mogą rozpętywać wojny, ciesząc się szerokim poparciem (Dewey 1927: 14, 26, 216). Dobra publiczne - a jeśli o to chodzi, również dobra prywatne - muszą wciąż być oceniane pod kątem merytorycznej treści.

Jak ogólna jest zatem Deweyowska idea tego, co „publiczne”? Czy jego pojęcie rządu jest przekonujące? W odróżnieniu od przywołanej wyżej teorii wyboru publicznego, Dewey twierdził, że choć niektórzy oficjele poszukują władzy i nagród, ludzie w ramach życia publicznego nie są koniecznie wiedzeni przez indywidualny interes własny, jak ma to miejsce na rynkach (Dewey 1927: 15, 21, 30). W USA idea Buchanana pojmującego politykę jako kolejny rynek zalegitymizowała plutokratyczne przechwycenie rządu (Stiglitz 2013). Korporacje posiadają polityków na własność, finansują ich kampanie, w zamian za co urzędnicy publiczni oddają im przysługi. W House of Cards wszystko to wygląda na coś zupełnie normalnego. Jednak czy są to nieuchronne cechy państw? Przyglądanie się funkcjonowaniu rządów na świecie wskazuje, że to raczej Dewey, a nie Buchanan, ma rację. Możemy dostrzec całą paletę zachowań. Rząd nie jest ani istotowo szlachetny, ani faktycznie skorumpowany. Nawet w USA nie można przeceniać neoliberalnego przemieszczenia ośrodka władzy. Rząd przynajmniej okresowo rozliczany jest w sposób oddolny. Wspólnym wysiłkiem zorganizowana opinia publiczna może uczynić szkolnictwo wyższe kwestią interesu publicznego oraz państwowej interwencji. Polityczna forma tego, co „publiczne”, uregulowanego przez rozróżnienie na państwo i nie-państwo, wciąż posiada pewną moc.

W jaki sposób można zastosować Deweyowską argumentację w przypadku państw, które nie są formalnie rozliczane w kategoriach politycznych? Nie wszystkie ISW rozmieszczone są w amerykańskich czy europejskich demokracjach, w których istnieją wolne wybory. W Chinach czy Singapurze opinia publiczna nie rozwija się w ramach otwartych forów obywatelskich, które wyobrażał sobie Dewey, oba państwa są jednak wrażliwe na opinię społeczeństwa, szczególnie tę, którą wyraża klasa średnia. Oba również dostosowują szanse edukacyjne i te związane z rynkiem pracy do jej oczekiwań (Goodman 2014). W czasie trzech tysięcy lat tradycji chińskiej cywilizacji państwo jest odpowiedzialne za społeczny dobrobyt i porządek. Kiedy słabnie w pełnieniu tej funkcji, wówczas traci powszechne przyzwolenie na swoje funkcjonowanie. Mówiąc bardziej ogólnie, Deweyowska idea tego, co publiczne, może zostać rozciągnięta $\mathrm{w}$ taki sposób, by obejmować wiele przypadków, w wielu społeczeństwach, gdy tylko rząd przewiduje konsekwencje konkretnych zjawisk dla stosunków społecznych, zanim zostanie na nie uwrażliwiony przez aktywną politykę ludową oraz fora uczestniczące. Deweyowska idea traci zastosowanie jedynie w odniesieniu do reżimów, w których rząd jest nieustannie obojętny wobec społecznej opinii. Niewiele systemów politycznych przyjmujących takie podejście jest w stanie przetrwać w dłuższej perspektywie. 


\subsection{Interes publiczny w szkolnictwie wyższym}

Jaki jest wobec tego publiczny i prywatny charakter szkolnictwa wyższego, który moglibyśmy uchwycić z wykorzystaniem Deweyowskiej politycznej definicji tego, co „publiczne”? Dla Samuelsona szkolnictwo wyższe jest publiczne jedynie, gdy nie może działać na rynku. Dla Deweya żaden lub wszystkie aspekty szkolnictwa wyższego mogą być publiczne lub prywatne. Potencjalnie edukacja lub badania są kwestią mającą publiczne konsekwencje, gdy dotyczą odpowiedniej liczby ludzi. Nawet prywatne szkolnictwo wyższe działające w sposób komercyjny jest kwestią publicznego interesu, jeśli ludzie i rządy określają, że powinno nią być.

Niemal we wszystkich systemach szkolnictwa wyższego - przy czym USA i Wielka Brytania są tu częściowymi wyjątkami - ISW postrzegane są jako organy publiczne. Polityczna definicja tworzy otwarte możliwości dla politycznych norm i wyborów. Jest bardziej skuteczna niż ekonomiczna definicja Samuelsona w rozpoznawaniu i regulowaniu dóbr kolektywnych, w rodzaju społecznej sprawiedliwości na uniwersytetach. Nie oznacza to, że wszelkie publiczne aspekty szkolnictwa wyższego powinny być ustalane przez państwo. W większości systemów szkolnictwa wyższego rząd przekazuje formalnie wiele spraw samym ISW. Jak już zauważono, to, co się różni, to zakres, w jakim to przekazanie władzy zagnieżdżone jest w celach politycznych z poziomu systemowego.

\subsection{Uniwersytet jako sfera publiczna}

Jürgen Habermas (2007) wyróżnił „sferę publiczną” ulokowaną między społeczeństwem obywatelskim a państwem. Jego przykładem był XVII-wieczny Londyn z jego salonami, kawiarniami i gazetami, które wspólnie ukonstytuowały opinię publiczną oraz zapewnily krytyczną refleksyjność współczesnemu porządkowi. Na podstawie koncepcji Habermasa Craig Calhoun (1992) ustalił, że uniwersytety działają w sposób analogiczny, jako nie w pełni niezależne uzupełnienia rządu, zapewniając konstruktywną krytykę oraz strategiczne możliwości wyboru, jak również informację, która pomaga państwu oraz opinii publicznej dojść do sformułowania przemyślanego stanowiska. Brian Pusser (2006) prezentuje uniwersytet jako obszar racjonalnej argumentacji oraz rywalizujących wartości, zauważając, że w Stanach Zjednoczonych szkolnictwo wyższe od zawsze było środkiem kolejnych politycznych i społeczno-kulturowych przekształceń w rodzaju ruchu praw obywatelskich w latach 60. XX wieku. Pojęcia tego, co publiczne, opierające się na rozróżnieniu tego, co państwowe i niepaństwowe, zwiększające zarazem złożoność „państwa”, mają swój oddźwięk w Chinach. To właśnie tam czołowe uniwersytety krajowe pełnią analogiczną rolę wewnątrz partyjnego państwa, rolę przestrzeni krytyki powiązanej z władzą (Yang 2009; Zha 2011). Uniwersytet Pekiński stanowił 
punkt wyjścia dla większości XX-wiecznych chińskich ruchów politycznych, w tym protestów na placu Tiananmen w 1989 r.

Ze względu na swoją rozwiniętą zdolność formowania samoprzekształcających się czynników oraz wywoływania intelektualnej refleksyjności (Castoriadis 1987: 372), jak również na sposób, w jaki umożliwia ruch ponad granicami; niekiedy, zarówno na Wschodzie, jak i na Zachodzie, szkolnictwo wyższe daje początek rozwiniętym formom demokratycznym. Wynika z tego, że jednym ze sprawdzianów stojących przed „publicznym” uniwersytetem jest weryfikacja skali, w jakiej zapewnia on przestrzeń dla krytyki, kwestionowania oraz nowych podstaw tego, co publiczne.

Habermasowska sfera publiczna jest oparta na komunikacji; niektórzy teoretycy definiują to, co „publiczne”, jako sieć publicznych i prywatnych organizacji tworzących wspólną przestrzeń komunikacyjną (np. Castells 2008; Drache 2008; Cunningham 2012). Podobnie jak Deweyowskie „to, co publiczne” czy Habermasowska sfera publiczna, tego rodzaju "quasi-publiczności” stanowią medium dla określonych wspólnot, w ramach których wymieniane są opinie - szkolnictwo wyższe, a szczególnie badania sprzyjają wielu takim usieciowionym wspólnotom, jednak w odróżnieniu od pojęć Deweya i Habermasa „quasi-publiczności” nie są definiowane przez odniesienie do państwa. Pokrywa się to z bardziej skomplikowaną i niejasną kategorią społeczeństwa obywatelskiego (Alexander 2006), w ramach której granice między tym, co publiczne i prywatne rozpuszczają się, a czasami również obejmuje ona rynek.

\section{7. Łączenie podejścia ekonomicznego i politycznego}

Każda z głównych definicji tego, co publiczne i prywatne ma swoje zalety i wady. Ekonomiczne podejście do tego, co „publiczne”, skupiające się na rozróżnieniu na to, co nierynkowe i rynkowe, jest mocniejsze w obszarze dóbr indywidualnych niż dóbr kolektywnych. Polityczne podejście, skupiające się przede wszystkim na rozróżnieniu na to, co państwowe i niepaństwowe, lepiej sobie radzi z kolektywnymi dobrami publicznymi, aspektami normatywnymi oraz dobrem publicznym (w liczbie pojedynczej). Ekonomiczna definicja określa niezbędne minimum dóbr publicznych, jednak samą relację między tym, co publiczne, a tym, co prywatne, przedstawia jako grę o sumie zerowej, ograniczając w ten sposób paletę wyborów politycznych. Polityczna definicja czyni relację publiczne - prywatne obszarem wyboru politycznego, nie zaś wydarzeniem naturalnym, umożliwiając tym samym uchylenie podejścia opartego na logice gry o sumie zerowej. Jest również znacznie wygodniejsze w obszarze normatywnym - to, co publiczne, jest tym, za czym opowie się opinia publiczna. Ma jednak tendencję do braku precyzji oraz nie ma wyraźnych granic. Deweyowskie rozumienie tego, co publiczne, jest w użyteczny sposób poddane dyscyplinie podejścia ekonomicznego opartego na rzadkości i kosztach. 
Pary pojęć nierynkowe - rynkowe oraz państwowe - niepaństwowe są heterogeniczne. Dotychczas postrzegano je jako oddzielne od siebie (lub w ramach imperialnych wyobrażeń dominujących dyscyplin jedno z podejść jest postrzegane jako nadbudowa drugiego). Prawdopodobnie jednak dwa pojęcia tego, co publiczne i prywatne splatają się ze sobą w praktyce; każde zaś ma swój wkład w rozumienie dynamiki tego, co publiczne i tego, co prywatne, każde wypełnia lukę w pozostałym, jak również dostarcza podstaw do krytycznej refleksyjności stosowanej w badaniu drugiego. Wynika z tego, że publiczny wymiar szkolnictwa wyższego można rozjaśnić, kreśląc dwie definicje wspólnie, dając każdej z nich taką samą wagę oraz utrzymując rozróżnienie między nimi. Dokonano tego na znajdującym się poniżej rysunku 1.

\section{Rama dla analizowania szkolnictwa wyższego i badań}

Rysunek 1 organizują dwie osie oparte na rozróżnieniu tego, co państwowe i niepaństwowe (oś wertykalna) oraz tego, co rynkowe i nierynkowe (oś horyzontalna). W ten sposób, siłą rzeczy, wytworzone zostają cztery kwadranty, które reprezentują

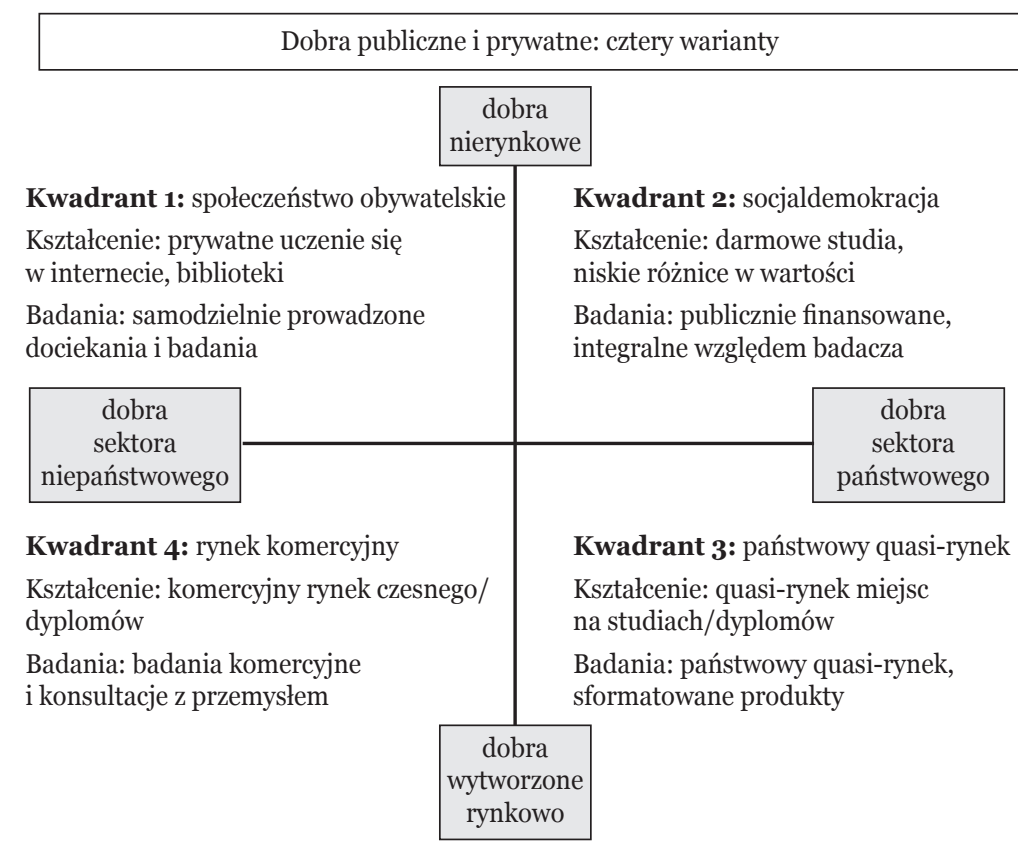

Rysunek 1. Łączenie ekonomicznej i politycznej definicji publicznych i prywatnych dóbr w szkolnictwie wyższym: cztery kwadranty - ekonomie polityczne szkolnictwa wyższego

Źródło: opracowanie własne. 
cztery ekonomie polityczne szkolnictwa wyższego. Aktywność edukacyjna i badawcza mogą zostać umieszczone na tym diagramie zgodnie z zakresem, w jakim są publiczne (nierynkowe) w ekonomicznym ujęciu Samuelsona, tym samym lokując się w kwadrancie 1 lub 2; oraz z zakresem, w którym są publiczne w politycznym sensie Deweya (uznawane za kwestię wspólnego interesu i objętą państwową kontrolą), a zatem ulokowane w kwadrancie 2 lub 3. Edukacja i badania, które są finansowane publicznie (stanowiąc ekonomiczne dobra publiczne), mogą być ściśle kontrolowane przez państwo w kwadrancie 2 lub stanowić finansowaną przez rząd aktywność w ramach społeczeństwa obywatelskiego w kwadrancie 1. Aktywność, która jest kontrolowana przez państwo (stanowi polityczne dobro publiczne), może być wytwarzana na nierynkowej podstawie w kwadrancie 2 lub prowadzona w oparciu o rynek oraz zasadę konkurencji i mieszane finansowanie w kwadrancie 3. „Czystym" publicznym kwadrantem, łączącym podejście ekonomiczne i polityczne, jest kwadrant 2.

Dwie niejasne kategorie tego, co publiczne, i tego, co prywatne, zostały zastąpione przez cztery jednoznaczne kategorie. Zarówno w badaniach, jak i w polityce publicznej te cztery odrębne ekonomie polityczne pozwalają na wyłonienie się jasnych porównań i kontrastów w ramach różnych typów kształcenia i badań, ułatwiając jednocześnie rozpoznanie odpowiedniej dynamiki ekonomiczno-politycznej oraz empirycznych obserwacji i pomiaru. Rysunek 1 pokazuje, że wyraźne stają się polityczne wybory powiązane z ekonomicznymi kwestiami zapewniania dostępu, np. tego, czy wytwarzać i dystrybuować wyższe wykształcenie jako powszechne nierynkowe dobro; czy opierając się na konkurencyjnej podstawie rynkowej, a jeśli to ostatnie, to czy wykorzystywać w tym celu kontrolowane przez państwo quasi-rynki (najbardziej powszechne podejście) w kwadrancie 3 czy też w pełni komercyjne rynki z kwadrantu 4. Uwypukla również kwestię tego, kto powinien płacić - czy państwo za pomocą podatków, czy też indywidualni beneficjenci. W kwestiach zdefiniowanych jako publiczne $\mathrm{w}$ sensie politycznym pomaga postawic pytanie o to, „na ile publicznym możemy sobie pozwolić się stać?” w kategoriach ekonomicznych.

Każdy z kwadrantów obejmuje przykłady typowych aktywności edukacyjnych i badawczych. Jeśli oceniamy ramę analityczną pod kątem zakresu udostępnianego przez nią wglądu w rzeczywistość, propozycja zawarta na rysunku 1 pod tym względem wypada całkiem dobrze, pozwala bowiem na wszechstronne spojrzenie na szkolnictwo wyższe. Jednak nieuchronnie niektóre działania umieszczone są na granicy między kwadrantami, przesuwając się między nimi z upływem czasu, lub też umieszczone są w więcej niż jednym kwadrancie.

Rzeczywiste systemy szkolnictwa wyższego, indywidualne ISW, nie są ulokowane wyłącznie w jednym kwadrancie. Niektóre działania mają miejsce we wszystkich kwadrantach. Równowaga jest zmienna. Przykładowo, większość aktywności w systemie nordyckim przypada na socjaldemokratyczny kwadrant 2, łącząc ze sobą 
również podejścia nierynkowe i bazujące na organizowaniu przez państwo, choć występują tam także mechanizmy konkurencyjne w rodzaju tych z kwadrantu 3 . Bardziej urynkowiony system amerykański jest silny w kwadrantach 3 i 4 , ale miesza to z ekonomicznymi i politycznymi dobrami publicznymi w kwadrancie 2, zaś podobnie jak inne systemy, obejmuje też część produkcji w kwadrancie 1. Habermasowska aktywność zachodząca w ramach sfery publicznej toczy się w kwadrancie 1 oraz 2. Obejmuje to również zbiorowy aktywizm studencki w kwadrancie 1.

\section{Kwadrant 1 (społeczeństwo obywatelskie)}

Kwadrant 1 utożsamia nierynkowe dobra wytworzone poza państwową kontrolą. Podobnie jak w kwadrancie 2, badania i kształcenie są nierywalizacyjnymi i niepodlegającymi wykluczeniu dobrami publicznymi w ujęciu Samuelsona. Nazwa tego kwadrantu jest o tyle kontrowersyjna, że w odróżnieniu od niektórych analiz w tym miejscu „społeczeństwo obywatelskie” oddzielone zostało zarówno od państwa, jak i od rynku. Jednakże, choć kwadrant 1 stanowi domenę prywatną, nie jest on domeną indywidualną czy rodziną oddzieloną od społeczeństwa. Jest relacyjnym i komunikacyjnym obszarem obejmującym sieci społeczne (kapitał społeczny) podtrzymywane za pośrednictwem uniwersytetów (Bourdieu 1986). Rozróżnienie między tym, co prywatne, a tym, co publiczne, nie jest równoważne z rozróżnieniem między jednostką a społeczeństwem (Dewey 1927: 69, 186). Jakakolwiek relacja między dwoma lub więcej osobami jest „społeczna”. Większość społecznych połączeń odbywa się w rzeczywistości prywatnej.

Kadra akademicka i studenci wykonują nieodpłatne i nieuregulowane aktywności w kwadrancie $1 \mathrm{w}$ przerwach między bardziej formalnymi codziennymi obowiązkami realizowanymi w innych miejscach. Otwarta wiedza z zakresu badań ma wiele relacyjnych konsekwencji, przepływa niczym woda przez wszystkie cztery kwadranty i nie jest politycznie publiczna, chyba że jest w określony sposób publicznie finansowana i/lub uregulowana, np. w ramach procedur ewaluacji badań.

\section{Kwadrant 2 (socjaldemokracja)}

W kwadrancie 2, obszarze socjaldemokratycznym, rama Samuelsona zostaje uzgodniona z propozycją Deweya - to, co publiczne, w znaczeniu państwa czy rządu, zbiega się z tym, co publiczne, w sensie tego, co nierynkowe. Kwadrant 2 łączy nierynkowe ekonomiczne dobra publiczne z politycznymi dobrami publicznymi, ukształtowanymi i w znacznej mierze finansowanymi przez procesy publiczne i rząd. Rząd administruje kształceniem/uczeniem się w oparciu o uniwersalną jakość bardziej niż wywoływaną rynkiem stratyfikację jakości, jak ma to miejsce w kwadrancie 3 czy 4 . W najbardziej egalitarnej wersji kwadrantu 2 nie ma opłat 
za studia, ich jakość jest wysoka, a wszystkie dyplomy mają istotną wartość, selektywność odgrywa zaś ograniczoną rolę. Badania w ramach kwadrantu 2 wspierane są przez ogólne finansowanie uniwersytetu. Projekty określane są przez ciekawość i ich walory merytoryczne, a nie związaną z konkurencyjnością przenikliwość czy sam status uniwersytetu. W nierynkowej produkcji na uniwersytetach nie występuje żadne naturalne ograniczenie dla ilości i jakości wytworów, za wyjątkiem całkowitego czasu pracy. Pojawić się mogą zaledwie utracone korzyści, gdy jedno działanie realizowane jest kosztem niepodjęcia innego. Jednakże rządy mogą kierować czy wpływać na produkcję.

Granica między kwadrantem 1 a 2 jest aktywna. Niektóre funkcje edukacyjne są „publiczne” w sensie publicznego konsensusu co do ich istoty (kwadrant 2), jednak podejmowane są częściej przez organizacje sektora pozarządowego (kwadrant 1) niż przez placówki rządowe. Przykładowo niemieckie kształcenie zawodowe jest „systemem półpublicznego samorządu”, w którym „partnerzy społeczni”, biznes i związki zawodowe, „przypisują publiczne obowiązki prywatnym firmom szkoleniowym" (Hansen 2011, 34).

\section{Kwadrant 3 (państwowy quasi-rynek)}

W okresie polityki neoliberalnej znaczna część aktywności w szkolnictwie wyższym przesuwana jest z kwadrantu 1 i 2 do kwadrantu 3. Quasi-rynki łączą rynki dóbr zdolnych do wykluczenia oraz pewnym stopniem rywalizacji z publicznymi funkcjami rządu. Elementem przecinającym wszystkie aktywności w ramach kwadrantu 3 jest organizowana przez rząd konkurencja. Jednakże niewiele quasi-rynków jest w pełni napędzanych zyskiem (Marginson 2015). Edukacja jest podporządkowana czesnemu, ustawodawcy podkreślają korzyści prywatne, mimo to miejsca na studiach są częściowo subsydiowane. W ramach projektów badawczych powstają produkty przypominające formą towary, ale pozostają one finansowane, a także kontrolowane przez rząd. Programy grantów badawczych często znajdują się na granicy kwadrantu 2 i 3. Gdy czesne osiąga bardzo wysoki poziom, wówczas państwowa edukacja przesuwa się bliżej kwadrantu 4.

W epoce neoliberalnej ekonomiczne i polityczne definicje tego, co publiczne i prywatne rozchodzą się ze względu na przesunięcie w kierunku quasi-rynków w kwadrancie 3, ekonomicznie prywatnych, ale politycznie publicznych. W kwadrancie 3 mamy zatem do czynienia ze stałym napięciem. Pod kontrolą rządową nie sposób zaspokoić żądań zwolenników w pełni rynkowej reformy, jednocześnie oczekiwania stworzone przez jego politycznie publiczny charakter (jego bliskość do kwadrantu 2) nieustannie zmieniają się w wyniku dynamiki rynkowej. Jeśli ISW byłyby w pełni skomercjalizowane, wówczas znajdowałyby się w kwadrancie 4, a Samuelson i Dewey spotkaliby się znowu, eliminując napięcie występujące między tymi podejściami. Jest to jednak niemożliwe ze względu na naturalny charakter 
wiedzy jako dobra publicznego. Jest także niemożliwe politycznie. Stawka, w tym kwestie sprawiedliwości społecznej, dla opinii publicznej i rządu jest zbyt wysoka, by pozwolić sobie na utratę szkolnictwa wyższego (Marginson 2015).

\section{Kwadrant 4 (rynek komercyjny)}

W kwadrancie 4 dobra z prywatnego rynku są również kontrolowane w sposób niepaństwowy. Państwo jest całkowicie nieobecne, ponieważ transakcje handlowe są uregulowane przez prawo handlowe, podobnie jak społeczeństwo obywatelskie w kwadrancie 1 uregulowane jest przez prawo cywilne i karne. Kwadrant 4 obejmuje badania komercyjne i konsultacje z przemysłem, jak również prowadzenie studiów dla zysku, w tym kształcenie zagranicznych studentów na uniwersytetach w Wielkiej Brytanii oraz Australii. Część aktywności komercyjnej jest ściśle regulowana czy subsydiowana, wpadając tym samym gdzieś pomiędzy kwadrant 3 i 4. Przykładowo ukierunkowane na zysk koledże w USA są subsydiowane przez federalne kredyty studenckie w ponad 80\% (Mettles 2014).

\section{Społeczna równość jako dobro publiczne}

Nacisk polityczny na sprawiedliwość społeczną w szkolnictwie wyższym, który często nie współgra z polityką ekonomiczną, wskazuje na nieustanne znaczenie demokratycznego, politycznego pojęcia wspólnego „interesu publicznego”, w którym, jak się uważa, wszyscy mają swój udział. Wiele zależy od tego, w jaki sposób rozumiana jest i praktykowana ta sprawiedliwość. W krajach anglojęzycznych edukacyjna sprawiedliwość społeczna postrzegana jest przede wszystkim w kategoriach indywidualnego dostępu do prywatnych ekonomicznych korzyści w ramach uwarstwionego systemu. Jednak tak rozumiana sprawiedliwość dotyczy również pytań o organizację systemu, która dotyczy tego, jak bardzo społecznie inkluzyjne są ISW, jak są społecznie uwarstwione, oraz dostępu i wzorców ukończenia edukacji wyższej w zależności od przynależności do grupy społecznej, a także zakresu, w jakim ISW sprzyjają społecznej mobilności (Corak 2012). Społeczna sprawiedliwość w szkolnictwie wyższym jest podstawą kolektywnych korzyści w rodzaju tych obecnych w kwadrancie 2, które z kolei podtrzymują potencjał wielu innych publicznych i prywatnych dóbr.

Jeśli wszystko inne pozostaje bez zmian, ruch z kwadrantu 2 do kwadrantu 3 wzmacnia instytucjonalną stratyfikację, ograniczenia finansowe oraz społeczną nierówność w odniesieniu do wzorców korzystania ze szkolnictwa wyższego, chyba że kompensuje efekty zwiększające nierówności początkowej niekorzyści i jej reprodukcji poprzez systematyczną i finansową stratyfikację (Marginson 2016a). We wszystkich krajach miejsca oferujące istotną przewagę pozycjonalną są często 
przechwytywane przez studentów z zamożnych rodzin, którzy są najlepiej przygotowani do konkurencji (Shavit, Arum i Gamoran 2007). ISW mogą wzmocnić początkowo tworzenie społecznych nierówności poprzez proces „skumulowanej przewagi" (DiPrete i Eirich 2006). Zauważmy jednak, że ekonomiczne dobro publiczne w kwadrancie 2 może zostać przechwycone przez uprzywilejowane grupy społeczne, podobnie jak ekonomiczne dobra prywatne w kwadrantach 3 i 4 . Nawet w systemach, gdzie nie ma czesnego, a ogólny etos jest inkluzyjny i egalitarny, rodziny o najlepszych zasobach kulturowych dla konkurencji akademickiej mogą zdominować dostęp do programów studiów, na które jest najwyższy popyt. Dlatego zawsze należy zadawać pytanie: „czyje dobra publiczne?”. Demokratyczne procesy polityczne powinny optymalizować egalitarną dystrybucję ekonomicznych dóbr publicznych, ale nie ma na to nigdy gwarancji.

Dobra pozycyjne nigdy nie są wyłącznie dobrami prywatnymi w sensie politycznym, szczególnie w przypadku miejsc na studiach o wysokiej wartości, które są ograniczone w zależności od popytu - nawet jeśli są prywatnymi dobrami w sensie ekonomicznym, jak również gdy dostarczane są przez prywatne uniwersytety. Gdy jedna osoba zyskuje dostęp do tego rodzaju dóbr, a inni są go pozbawieni, wówczas kształtuje się wzorzec władzy społecznej i nagród ekonomicznych, wpływając na wszystkich studentów i ich rodziny. Intensywna ekonomiczna konkurencja o dobra związane ze statusem z górną granicą nałożoną na ich dystrybucję również tworzy pewne marnotrawstwo (Cooper, Garcia-Penalosa i Funk 2001). Kwestie publicznych „konsekwencji” o znaczeniu dla stosunków społecznych w ujęciu Deweya nadają się do upolitycznienia oraz państwowej regulacji. Jak na ironię, te same cechy relacyjne, które umożliwiają wytworzenie wysokiej wartości edukacji jako Samuelsonowskich dóbr prywatnych, otwierają je również na publiczną, polityczną interwencję. Jest to jeden z powodów, dla których polityka edukacyjna jest niestabilnym polem nieustannych negocjacji.

\section{Globalne dobra publiczne}

Cały zakres multilateralnych procesów działa w przestrzeni globalnej, a globalne organizacje polityczne w rodzaju Banku Światowego, OECD czy agencji Organizacji Narodów Zjednoczonych mogą wpływać na wiele krajów. Organizacje te odpowiadają przed grupami oraz interesami pochodzącymi z wielu krajów. Jednak globalna publiczna produkcja jest ograniczona przez nieobecność globalnego państwa zdolnego do Deweyowskiego rozwiązywania ponadgranicznych spraw posiadających relacyjne konsekwencje. Bez wątpienia prowadzi to do niedostatecznego rozpoznania wkładu szkolnictwa wyższego w pulę globalnych dóbr publicznych, jak również do ich niedostatecznego zapewniania (Marginson, Murphy i Peters 2010). 
W sferze globalnej zaledwie jedno rozróżnienie na to, co publiczne i prywatne ma zastosowanie, to znaczy rozróżnienie ekonomiczne Samuelsona. Pod tym względem globalne dobra publiczne są „dobrami, które posiadają istotny komponent nierywalizacyjności i/lub niepodlegania wykluczeniu, jak również są szeroko udostępniane ludności na skalę globalną. Wpływają na więcej niż jedną grupę krajów" (Kaul, Grunberg i Stern 1999: 2-3). Kraje różnią się zakresem, w jakim mają wkład w globalne dobra publiczne dostarczane za pomocą ponadgranicznych przepływów wiedzy, idei i ludzi oraz wytwarzanych w ramach kształcenia i badań, jak również zakresem, w jakim z nich czerpią. Dajmy na to, zawartość globalnych przepływów wiedzy jest językowo i kulturowo zdominowana przez określone kraje, w szczególności przez USA. To raz jeszcze podsuwa nam pytanie „czyje dobra publiczne?”. Dla kadry akademickiej mówiącej po hiszpańsku język angielski jako pojedynczy wspólny, globalny język jest dobrem publicznym w tym sensie, że umożliwia tworzenie otoczenia służącego nawiązywaniu relacji. Jednocześnie jest on „publicznym złem" (public bad) (negatywnym, globalnym efektem zewnętrznym) ze względu na to, w jakim zakresie marginalizuje wiedzę tworzoną w języku hiszpańskim na poziomie globalnym. Może również prowadzić do dewaluacji wiedzy nawet w otoczeniu hiszpańskojęzycznym, np. wiedzy lokalnych wspólnot naukowych. Kraje rozwijające się mogą doświadczać drenażu mózgów personelu badawczego do globalnych metropolii, co jest kolejnym „publicznym złem”.

Istnieje zarazem wiele nieformalnych globalnych, komunikacyjnych sfer publicznych, które przekraczają granice, w tym obfitość podobnych relacji mających miejsce w sektorze uniwersyteckim. Globalne „quasi-sfery publiczne” obejmują sieci komunikacyjne w rodzaju Google czy Facebooka, znajdując się na granicy między kwadrantem $1 \mathrm{a}$ 4, ale cechując się powstającym potencjałem politycznym. Niemniej włączenia w obręb globalnej wspólnoty są względnie słabe - więzy nie są tak silne jak w ramach krajowej polityki - a kwestie „publiczne” w tym sensie niekoniecznie przekładają się na skoordynowane działanie. Firma komunikacyjna nie jest państwem. Nie jest zobowiązana do odpowiadania na opinie, choć będzie na nie zawsze wrażliwa ze względów komercyjnych. Jednakże te niepaństwowe sfery publiczne, które w sposób wolny przekraczają granice między krajowymi politykami, wpływają również na państwa narodowe. Podobnie ponadgraniczne relacje między uniwersytetami wyprzedziły relacje między krajami. Nie ma jasności co do tego, kiedy i jak polityczne kształtowanie globalnych dóbr publicznych nadrobi te zaległości.

\section{Wnioski oraz kolejne kroki}

Ekonomiczna definicja tego, co publiczne i prywatne w szkolnictwie wyższym, oparta na rozróżnieniu tego, co nierynkowe i rynkowe, podporządkowuje politycznie 
określone dobra publiczne próbom ograniczonych zasobów i kosztów. Zadaje pytanie o to, ,jak publicznie hojne powinno być zapewnianie edukacji wyższej?”. Polityczna definicja tego, co publiczne i prywatne w szkolnictwie wyższym, oparta na rozróżnieniu tego, co państwowe i niepaństwowe, podporządkowuje ekonomicznie określone dobra publiczne i prywatne próbom wartości, norm, stosunków społecznych oraz projektu danego systemu. Twierdzi się zatem, że „publiczne i kolektywne formy zapewniania edukacji wyższej mogą zmienić istotę dóbr, np. związaną z nimi społeczną sprawiedliwość”. „Jakiego rodzaju społeczeństwa chcecie?”. Odpowiedź brzmi: „W zakresie, w jakim preferowana przez was umowa społeczna jest poddana zawodności rynku, rząd ją finansuje. Czy jednak stać nas na to?”. Dobra publiczne i prywatne są heterogeniczne pod względem ich wartości użytkowych, jednakże można je wiązać ze sobą w obrębie jednego systemu wartości monetarnych. Razem ekonomiczne i polityczne tryby tworzą ramę o większym potencjale eksplanacyjnym i pomocniczym dla operacjonalizacji rozróżnienia na to, co publiczne i prywatne w szkolnictwie wyższym, niż są w stanie zapewnić w pojedynkę.

Podsumowując, polityczno-ekonomiczna istota szkolnictwa wyższego i badań określona jest przez to, czy konkurencja rynkowa wykorzystywana jest do koordynacji $i / l u b$ czy dana aktywność ulokowana jest w sektorze państwowym lub ściśle przez niego kontrolowana. „Sektor państwowy” obejmuje w tym przypadku zarówno prawnie posiadane przez państwo placówki, jak i te nominalnie prywatne, które kontrolowane są przez państwo w takim stopniu, że stanowią ekwiwalent placówek państwowych. Ta ostatnia kategoria obejmuje uregulowane i sfinansowane przez rząd sektory prywatnego szkolnictwa wyższego czy instytucje w niektórych krajach, takie jak uniwersytety w Wielkiej Brytanii, dziś nominalnie prywatne w sensie prawnym, ale wywodzące się z publicznych. Kwestia finansowania jest drugorzędna wobec publicznie-prywatnego charakteru. Pobieranie wysokiego czesnego jest czymś symptomatycznym dla relacji rynkowych (kwadranty 3 lub 4), ale niskie czesne, które nie oznacza konkurencji czy barier w dostępie, jest kompatybilne z dolnymi częściami kwadrantu 2. Podczas gdy rządowe finansowanie jest kluczowe dla kwadrantu 2, jest ono w sposób normalny obecne w kwadrancie 3, a mogą istnieć również publiczne subsydia aktywności komercyjnej w kwadrancie 4.

Problemy te wyglądają odmiennie w zależności od kraju. Systemy różnią się zakresem, w jakim wytwarzają kształcenie oraz badania jako dobra prywatne w sensie ekonomicznym, to znaczy dóbr rynkowych. Kraje różnią się również tym, jakie aspekty szkolnictwa wyższego zyskują polityczną uwagę i poddawane są państwowej regulacji; tym, jakiego rodzaju dóbr kolektywnych oczekuje się od ISW, oraz tym, jak filozoficznie rozumie się relacyjny aspekt tego, co publiczne. Porównując ze sobą różne podejścia zarówno do nierynkowych, jak i politycznych publicznych aktywności w szkolnictwie wyższym na podstawie danych empirycznych, możliwe jest rozwinięcie wielopozycyjnego (Sen 1992), generycznego języka tego, co pu- 
bliczne i prywatne, który byłby zakorzeniony w jedności-w-różnorodności. To natomiast mogłoby sprzyjać rozpoznaniu i produkcji nie tylko krajowych, ale również globalnych dóbr publicznych w ramach uniwersyteckiej edukacji i badań. Są to właśnie kolejne kroki wynikające z prezentowanych w niniejszym artykule dociekań.

przełożył Krystian Szadkowski

\section{Literatura}

Alexander, J. (2006). The Civil Sphere. New York: Oxford University Press.

Amadae, S.M. (2003). Rationalizing Capitalist Democracy: The Cold-war Origins of Rational Choice Liberalism. Chicago: University of Chicago Press.

Arrow, K. (1951/2012). Social Choice and Individual Values. Eastford, CT: Martino Fine Books.

Bourdieu, P. (1986). The Forms of Capital. W: J. Richardson (red.). Handbook of Theory and Research for the Sociology of Education (241-258). New York: Greenwood.

Buchanan, J. (1965). An Economic Theory of Clubs. Economica. 32(125): 1-14.

Buchanan, J., Tullock, G. (1962). The Calculus of Consent. Anna Arbor: University of Michigan Press.

Calhoun, C. (1992). Introduction. W: C. Calhoun (red.). Habermas and the Public Sphere (1-48). Cambridge, MA: The MIT Press.

Castells, M. (2000). Spoteczeństwo sieci. Tłum. M. Marody, K. Pawluś, J. Stawiński, Warszawa: Wyd. Naukowe PWN.

Castoriadis, C. (1987). The Imaginary Institution of Society. Cambridge: Polity Press.

Cooper, B., Garcia-Penalosa, C., Funk, P. (2001). Status Effects and Negative Utility Growth. The Economic Journal. 111: 642-665.

Corak, M. (2012). Inequality from Generation to Generation: The United States in Comparison. Ottawa: Graduate School of Public and International Affairs, University of Ottawa.

Cunningham, S. (2012). Hidden Innovation: Policy, Industry and the Creative Sector. Brisbane: University of Queensland Press.

Dewey, J. (1927). The Public and its Problems. New York: H. Holt.

DiPrete, T., Eirich, G. (2006). Cumulative Advantage as a Mechanism for Inequality: A Review of Theoretical and Empirical Developments. Annual Review of Sociology. 32: 271297.

Dirks, N. (2015). The Future of World-class Universities. University World News 384, 2 października. http://www.universityworldnews.com/article.php?story=20151001004022 774\&query=dirks [20.02.2017].

Drache, D. (2008). Defiant Publics: The Unprecedented Reach of the Global Citizen. London: Polity Press.

Geiger, R., Sa, C. (2009). Tapping the Riches of Science: Universities and the Promise of Economic Growth. Cambridge, MA: Harvard University Press.

Goodman, D. (2014). Class in Contemporary China. Cambridge: Polity Press. 
Habermas, J. (2007). Strukturalne przeobrażenia sfery publicznej. Tłum. W. Lipnik, M. Łukasiewicz. Warszawa: Wyd. Naukowe PWN.

Hansen, H. (2011). Rethinking Certification Theory and the Educational Development of the United States and Germany. Research in Social Stratification and Mobility. 29: 31-55. Hirsch, F. (1976). Social Limits to Growth. Cambridge, MA: Harvard University Press.

Hughes, A., Kitson, M. (2012). Pathways to Impact and the Strategic Role of Universities: New Evidence on the Breadth and Depth of University Knowledge Exchange in the UK and the Factors Constraining its Development. Cambridge Journal of Economics. 36: 723-750.

Kaul, I., Grunberg, I., Stern, M. (red.) (1999). Global Public Goods: International Cooperation in the Twenty-first Century. New York: Oxford University Press.

Mansbridge, J. (1998). On the Contested Nature of the Public Good. W: W. Powell, E. Clemens (red.). Private Action and the Public Good (3-19). New Haven: Yale.

Marginson, S. (2007). The Public/Private Division in Higher Education: A Global Revision. Higher Education. 53: 307-333.

Marginson, S. (2011). Higher Education and Public Good. Higher Education Quarterly. 65 (4): 411-433.

Marginson, S. (2013a). Higher Education and Public Good. W: P. Gibbs, R. Barnett (red.). Thinking About Higher Education (53-69). Heidelberg: Springer.

Marginson, S. (2015). O niemożliwości zaistnienia kapitalistycznych rynków w szkolnictwie wyższym. Tłum. K. Szadkowski. Nauka i Szkolnictwo Wyższe. 1(45): 11-37.

Marginson, S. (2016a). The Worldwide Trend to High Participation Higher Education: Dynamics of Social Stratification in Inclusive Systems. Higher Education. 72(4): 413-434.

Marginson, S. (2016b). The Dream is Over: The Crisis of Clark Kerr's Californian Idea of Higher Education. Berkeley: University of California Press.

Marginson, S., Murphy, P., Peters, M. (2010). Global Creation: Space, Mobility and Synchrony in the Age of the Knowledge Economy. New York: Peter Lang.

Mauss, M. (2001). Szkic o darze. Forma i podstawa wymiany w społecznościach archaicznych. W: Socjologia i antropologia, przeł. M. Król, K. Pomian, J. Szacki, Kraków: KR.

McMahon, W. (2009). Higher Learning Greater Good. Baltimore, MD: The Johns Hopkins University Press.

Mettler, S. (2014). Degrees of Inequality: How the Politics of Higher Education Sabotaged the American Dream. New York: Basic Books.

OECD (2014). Education at a Glance. Paris: Organisation for Economic Cooperation and Development.

Ostrom, E. (2010). Beyond Markets and States: Polycentric Governance of Complex Economic Systems. American Economic Review. 100: 641-672.

Prendergast, R. (2010). Accumulation of Knowledge and Accumulation of Capital in Early 'Theories' of Growth and Development. Cambridge Journal of Economics. 34: 413-431.

Pusser, B. (2006). Reconsidering Higher Education and the Public Good. W: W. Tierney (red.). Governance and the Public Good (11-28). Albany, NY: SUNY Press.

Romer, P. (1990). Endogenous Technological Change. Journal of Political Economy. 98: S71-S102. 
Rothblatt, S. (2012). Clark Kerr: Two Voices. W: S. Rothblatt (red.). Clark Kerr's World of Higher Education Reaches the Twenty-first Century: Chapters in a Special History (142). Dordrecht: Springer.

Samuelson, P. (1954). The Pure Theory of Public Expenditure. Review of Economics and Statistics. 36(4): 387-389.

Sen, A. (1992). Objectivity and Position. The Lindley Lecture, The University of Kansas. Lawrence, KS: The University of Kansas.

Shavit, Y., Arum, R., Gamoran, A. (red.) (2007). Stratification in Higher Education: A Comparative Study. Stanford: Stanford University Press.

Stiglitz, J. (1999). Knowledge as a Global Public Good. W: I. Kaul, I. Grunberg, M. Stern (red.). Global Public Goods: International Cooperation in the Twenty-first Century (308-325). New York: Oxford University Press.

Stiglitz, J. (2013). The Price of Inequality. London: Penguin.

Välimaa, J. (2011). The Corporatization of National Universities in Finland. W: B. Pusser, K. Kempner, S. Marginson, I. Ordorika (red.). Universities and the Public Sphere (101119). New York: Routledge.

Yang, R. (2009). Enter the Dragon? W: J. Smart (red.). Higher Education: Handbook of Theory and Research (427-461). Dordrecht: Springer.

Zha, Q. (2011). Is there an Emerging Chinese Model of the University? W: R. Hayhoe, J. Li, J. Lin, Q. Zha (red.). Portraits of Twentyfirst Century Chinese Universities (451-471). Hong Kong: Springer/CERC, University of Hong Kong.

\title{
Public/private in higher education: A synthesis of economic and political approaches
}

\begin{abstract}
The public/private distinction is central to higher education but there is no consensus on 'public.' In neo-classical economic theory, Samuelson distinguishes non-market goods (public) that cannot be produced for profit, from market-based activity (private). This provides a basis for identifying the minimum necessary public expenditure, but does not effectively encompass collective goods, or normative elements. In political theory 'public' is often understood as state ownership and/ or control. Dewey regards social transactions as 'public' when they have relational consequences for persons other than those directly engaged, and so become matters of state concern. This is more inclusive than Samuelson but without limit on costs. Neither definition is wholly satisfactory, each offers something, and each can be used to critically interrogate the other. The article synthesizes the two approaches, applying the resulting analytical framework with four quadrants (civil society, social democracy, state quasi-market and commercial market) to higher education and research.
\end{abstract}

KEYWORDS: role of higher education, equality, neoliberalism, public policy, education market

CYTOWANIE: Marginson, S. (2016). To, co publiczne i prywatne w szkolnictwie wyższym: synteza podejścia ekonomicznego i politycznego. Tłum. K. Szadkowski, Nauka i Szkolnictwo Wyższe. 2(48): 18-40. DOI: 10.14746/nisw.2016.2.1. 